\title{
Evaluation of Water Stress on Yield, Its Components and Some Physiological Traits at Different Growth Stages in Grain Sorghum Genotypes
}

\author{
Ali AZARINASRABAD ${ }^{1,2 *}$, Seyyed Mohsen MOUSAVINIK ${ }^{2}$, Mohammad \\ GALAVI $^{2}$, Seyyed Alireza BEHESHTI ${ }^{3}$, Alireza SIROUSMEHR ${ }^{2}$
}

\author{
'South Khorasan Agricultural and Natural Resources Research and Education Center, Seed and Plant Improvement Research Department, AREEO, Birjand, \\ Iran;azari_ali2003@yahoo.com (*orrespondingauthor) \\ 2ZabolUniversity,Faculty of Agriculture,Zabol,Iran;mousavi@uozac.ir;mgalavi@yahoo.com; asirousmehr@uozac.ir
}

${ }^{3}$ Khorasan Razavi Agricultural and Natural Resources Research and Education Center, Seed and Plant Improvement Research Department, AREEO, Mashhad,

Iran;arbeheshti81@yahoo.com

\begin{abstract}
Investigation on yield improvement and development under drought condition using breeding techniques is difficult, due to the association with low heritability of specific traits. Even more, investigation of physiological indicators (stomatal conductance, chlorophyll index, relative water content, chlorophyll fluorescence, canopy temperature, radiation use efficiency, stay-green etc.) is of interest as they are more accessible, with a low cost, therefore these indicators of physiological traits can be used as good criteria in selecting valuable species. In order to evaluate the effects of water stress on grain yield, its components and some physiological traits of grain sorghum genotypes (Sorghum bicolor L.), a field experiment using split plot design with three replications was carried. The main plots included three water stress treatments: normal irrigation as control, halting irrigation at the stage of terminal leaf emergence and halting irrigation at the stage of $50 \%$ flowering. The sub-plots included 10 genotypes of sorghum ('KGS29', 'MGS2', 'Sepideh', 'KGFS27', 'MGS5', 'KGFS5', 'KGFS17', 'KGFS13' and 'KGFS30'). Results showed that water stress significantly decreased grain yield and its components (1,000 seed weight, number of seed per panicle) and had various effects on physiological traits. The water stress increased canopy temperature and radiation use efficiency, while stomatal conductance, chlorophyll index (SPAD) and stay-green of genotypes were decreased; the maximum efficiency of photosystem II of photosynthesis remained unchanged between the treatments. Genotypes turned out to have significantly different responses to the drought treatments for all the studied traits, indicating the existence of a high variability among them. In general, physiological traits could be used as good indicators in water stress investigations and might provide comprehensive information as compared with morphological traits.
\end{abstract}

Keywords: generative growth, RUE, sorghum, water stress, yield

\section{Introduction}

Water is the most limiting factor in agriculture. In arid and semiarid regions of the world, including Iran, water scarcity is a serious obstacle and for that reason determination of plants' relative tolerance to drought is of particular interest (Entz and Flower, 1990). Nevertheless, water stress can negatively affect sorghum growth at late stages including pollination, resulting in a major yield reduction (Tuinstra et al., 1997; Prasad et al., 2008).

The yield of grain sorghum is dependent on the number of panicle per unit area or per plant, number of seeds per panicle and the one thousand grain weight (Maman et al., 2004). To select drought tolerant genotypes and germplasm, the yield components can be used as handy and straight forward attributes (Richards, 1996). In a water stress related research program, there is a need to have adequate information on significant relations between the recorded traits and yield components (Schaffert et al., 2011). Such information will help to acquire suitable genotypes with desirable characteristics under stress condition (Ali et al., 2009). For instance, Aruna and Audilakshm (2008) showed a positive relation between panicle thickness and one thousand grain weight of sorghum, which is important when selecting high yield genotypes.

Water shortage and drought stress greatly damage sorghum growth at flowering stage (from 10 days before initiation of flowering until the stage flowering is completed). This period is critical and can significantly reduce grain yield (Prasad et al., 2008).

Drought stress affects physiological, biochemical and molecular aspects of photosynthesis. It can reduce the flow of $\mathrm{CO}_{2}$ through the leaf mesophyll tissue by regulating stomatal closure, causing damages to the synthesis of ATP, as well as 
reducing the Rubisco activity (Chaves et al., 2003; Flexas et al., 2004). The first impact of drought stress is to reduce stomatal conductance, which directly declines the rate of photosynthesis (Cornic, 2000). It has been suggested that non-stomatal constrains, such as oxidative damages to chloroplasts along with the stomatal closure effects, are responsible for reducing photosynthesis under drought stress condition (Zhou et al., 2007). In moderate drought conditions, stomatal closure reduces the flow of $\mathrm{CO}_{2}$ that is a limiting factor for photosynthesis. The reduction in stomatal conductance decreases internal $\mathrm{CO}_{2}$ concentration $(\mathrm{Ci})$ which in turn mitigate $\mathrm{CO}_{2}$ emissions into mesophilic cell wall, membrane, cytoplasm, that eventually reduces $\mathrm{CO}_{2}$ concentrations of chloroplasts (Terashima and Ono, 2002). In severe water shortage conditions, drought stresses affect the whole capacity of the mesophilic photosynthesis. The results will have a sharp decrease in carboxylation process and electron transport chain activity, which induce structural destruction to the chloroplasts (Mutava, 2012).

Temperature measurement of a plant canopy as an indication of plant water content and has a long history in research (Kluitenberg and Biggar, 1992). Using canopy temperature as an indicator is based on the assumption that transpiration cools off the leaves. When the plant access to water is limited, transpiration declines and leave's temperature rises due to the continuing absorption of radiation (Jensen et al., 1990). Canopies with high temperatures mean low stomatal conductance and high transpiration efficiency, considering both as desirable traits as far as adaptation to drought is concerned (Mutava, 2012). It is reported that under drought conditions, the cultivars with lower canopy temperatures had almost $10 \%$ rises in yield (Reynolds et al., 2007). They also found that the canopy temperature had correlations with water absorption and the stomatal conductance.

Drought has a destructive effect on chloroplasts, but the damage is less likely to happen in tolerant sorghum cultivars than the sensitive ones due to magnesium in their cells (Lichtenthaler, 1998). Long term environmental stress could be studied using the ratio of fluorescence absorption at 690 to $735 \mathrm{~nm}$ wavelength. In leaves that are in normal stress condition, a large part of the fluorescence could be absorbed at $690 \mathrm{~nm}$, while the absorption is highly limited at $735 \mathrm{~nm}$; that is why the ratio increases under stress conditions (Lichtenhaler, 1998). The analysis of chlorophyll fluorescence is a quick and non-destructive method for evaluating the performance of the photosynthetic system during and after the stress events. Therefore, the decreasing level of maximum quantum efficiency of photosystem II $(\mathrm{Fv} / \mathrm{Fm})$ and the stable fluorescence changes $(\mathrm{Fv}=\mathrm{Fm}-\mathrm{F} 0)$ in a given time period are used as a measure of tolerance and resistance to drought stress (Grafts-Brander and Salvucci, 2002; Yamasaki et al., 2002).

Relative water content (RWC) has shown to be affected under stress conditions. Kumari Vinodhana and Ganesamurthy (2010) observed that sorghum genotypes with higher relative water content had higher relative yield and resistance to drought and less sensitivity to the stress imposed. Radiation use efficiency (RUE) was also reported to be high in sorghum (Rosenthal et al., 1993), as the plant is considered to be the most tolerant crop to drought (Blum, 2004) with intraspecific variation of RUE (Hammer et al., 2010). Green leaf area at the time of physiological maturity (GLAM) can be a good indicator of sorghum stay-green (Borrell et al., 2000). This index can be visually assessed by counting the number of green leaves at any stages (Wanous et al., 1991). It is reported that GLAM in sorghum has a high positive correlation with green leaves under drought stress (Wanous et al., 1991).

The objective of this study was to evaluate the effects of water stress on grain yield under field condition, sorghum yield components and some physiological traits of grain sorghum genotypes.

\section{Materials and Methods}

\section{Description of the study site}

The experiment was undertaken at research station of the Southern Khorasan Agriculture and Natural Resources Research and Education Center in 2014. Birjand is located on the South --East part of Iran at 32 $52^{\prime} 26^{\prime \prime} \mathrm{N}$ latitude and $59^{\circ} 12^{\prime} 51^{\prime \prime} \mathrm{E}$ longitude. The average temperature and the amount of relative humidity in growing season of 2014 were $29^{\circ} \mathrm{C}$ and $28 \%$, respectively. Soil characteristics were texture being loam, $\mathrm{EC}=3.21(\mathrm{ds} / \mathrm{m})$ and soil $\mathrm{pH}=8.14$.

\section{Crop growing conditions and husbandry}

The regional climate is mild with a dry temperature, and the average annual rainfall is $147 \mathrm{~mm}$. Land preparations, including ploughing and levelling, was performed in fall and spring and fertilisation was applied according to the soil test results. Urea at a rate of $400 \mathrm{~kg}$ per hectare in two stages (one-third at planting time and two-thirds one month after), triple super phosphate at a rate of $200 \mathrm{~kg}$ per hectare and potassium sulphate at a rate of $150 \mathrm{~kg}$ per hectare at the time of planting were given. Weed control was conducted on a periodic basis by hand weeding throughout the experiment. Planting was carried out in May after the soil temperature reached to $12^{\circ} \mathrm{C}$.

\section{Biologicalmaterial}

In this study 10 genotypes of sorghum named as 'KGS29', 'MGS2', 'Sepideh', 'KGFS27', 'MGS5', 'KGFS5', 'KGFS17', 'KGFS13' and 'KGFS30' were studied.

\section{Experimental design}

A field experiment was carried using a split plot design with three replications. Main plots included drought stress treatments (normal irrigation as control, irrigation halt at the end of vegetative growth when terminal leaf was observed and irrigation halt at the initial stage of $50 \%$ flowering). The subplots comprised from the 10 genotypes of sorghum named.

Several physiological traits (leaf relative water content, stomatal conductance, canopy temperature, chlorophyll index, quantum yield, radiation use efficiency, stay-green, yield and its components), grain yield and its components were recorded.

\section{Collecting data}

For the yield components to be determined, half a meter long quadrate was randomly placed in each plot and number of plants per unit area, number of panicle in each plant, number of seeds per panicle and the 1,000 seed weight were measured. After elimination of margin effect, grain yield was calculated using a three square meter plot. The plants in 
206

each plot were harvested to the ground and dried. They were then crushed by hand and the grain separated and weighed.

To calculate the relative water content (RWC), flag leaf samples were taken from each plot and weighed immediately. They were then refrigerated for 24 hours in distilled water until reaching their full swelling. The samples were weighted after removing the excess moisture from their surfaces using paper tissues and then placed into an oven set at $72^{\circ} \mathrm{C}$ for 48 hours. The samples were weighted after oven drying and the leaf relative water content was calculated using Weatherley formula (Weatherley, 1950).

Stomatal conductance was measured twice with one month in between, using a Porometer device Model EGM4 PP Systems. The measurements were carried out on the flag leaf of three plants in each plot at 9:00 in the morning. Canopy temperature was recorded using an infrared thermometer. The canopy temperature was recorded at 70 $90 \mathrm{~cm}$ height, from different directions and the data was then averaged to compute the mean value for each plot.

Chlorophyll index of the flag leaf was measured using a SPAD device Model 502 Minolta, twice in 30 days. The values recorded at the beginning, middle and the end parts of the leaves of three plants were averaged to calculate the mean for each plot. Chlorophyll fluorescence measurements were also performed at similar time and the leaf parts, using a portable stress meter.

To measure the stay-green at physiological maturity, a visual scoring method representing 1 as the lowest and 5 as the highest values was adopted (Wanous et al., 1991). Radiation measurement in each plot was carried out at the top $\left(\mathrm{I}_{0}\right)$ and at the bottom (I) of the canopy. In each plot two measurements (one perpendicular to the rows and the other alongside the rows) were performed between 11:00 and 13:00 using a Ceptometer device model AccuPAR LP80 Decagon.

Radiation use efficiency (RUE) was calculated by dividing Totall Dry Matter (TDM) to light absorption (Monteith, 1977). For each plot, light extinction coefficient (k) and canopy radiation absorption (Ii) (AghaAlikhani et al., 2012) were calculated using equations 1 and 2 respectively.

Equation 1

$$
\mathrm{K}=\frac{-\ln \frac{\mathrm{I}}{\mathrm{I}_{\mathrm{g}}}}{\mathrm{LAI}}
$$

$$
\begin{aligned}
& \text { Equation } 2 \\
& \qquad I_{\mathrm{i}}=\mathrm{I}_{0}\left(\exp ^{(-\mathrm{K} . \mathrm{LAA})}\right)
\end{aligned}
$$

Where $\left(\mathrm{I}_{0}\right)$ and $(\mathrm{I})$ are radiation measurement in each plot at the top and bottom of the canopy, respectively; $(\mathrm{k})$ indicate light extinction coefficient, (Ii) is canopy radiation absorption and (LAI) is leaf area index for each plot.

\section{Statistical procedures}

Data were analysed by statistical analysis system (SAS) software version 9.1 using analysis of variance (ANOVA) and differences among means were determined for significance at $\mathrm{P}<0.05$ using LSD test.

\section{Results and Discussion}

Analysis of variance showed that drought stress had significant effects on grain yield $(\mathrm{P}<1 \%)$, number of grains per panicle and 1,000 seed weight $(\mathrm{P}<5 \%)$. Genotypes also showed statistically significant differences on the above mentioned traits $(\mathrm{P}<1 \%)$. Interaction between drought stress and genotype had significant effect on the above traits $(\mathrm{P}<1 \%)$ but not on 1,000 seed weight (Table 1).

Means comparison showed that grain yield decreased with the increase in drought stress. Table 2 shows that grain yield was $3,335 \mathrm{~kg}$ per hectare in control (no stress), $2,488 \mathrm{~kg}$ per hectare (25\% decrease compared with control) in irrigation halt at reproductive stage (medium stress) and 1,641 kg per hectare (51\% decrease compared with control) in irrigation halt at vegetative stage (severe stress). Amongst the genotypes, grain yield was the highest $\left(5,060 \mathrm{~kg} \mathrm{ha}^{-1}\right)$ in 'KGF13' and the lowest $\left(1,741 \mathrm{~kg} \mathrm{ha}^{-1}\right)$ in 'KGS33'. The interaction between the factors showed that 'KGF13' maintained the highest grain yield at zero and medium drought stresses and 'KGF5' acquired the lowest amount in severe stress condition (Table 3).

The 1,000 seed weight decreased with drought stress obtaining 25.5, 23.2 and $21.3 \mathrm{~g}$ as the stress increased from zero to severe level. In comparison with the zero stress, such decrease in 1,000 seed weight accounts for 9 and 19\% in medium and severe stress respectively. Grain number per panicle was also significantly affected by drought with

\begin{tabular}{|c|c|c|c|c|c|c|c|c|c|c|c|c|}
\hline S.O.V & $\mathrm{df}$ & $\begin{array}{c}\text { Stomatal } \\
\text { conductance }\end{array}$ & $\begin{array}{c}\text { Canopy } \\
\text { temperature }\end{array}$ & $\begin{array}{c}\text { Relative } \\
\text { water } \\
\text { content } \\
\text { (RWC) }\end{array}$ & $\begin{array}{l}\text { Chlorophyll } \\
\text { index } \\
\text { (SPAD) }\end{array}$ & $\begin{array}{l}\text { Radiation } \\
\text { use } \\
\text { efficiency } \\
\text { (RUE) }\end{array}$ & $\begin{array}{l}(\mathrm{FV} / \mathrm{Fm}) \\
\text { of 1st date }\end{array}$ & $\begin{array}{l}(\mathrm{FV} / \mathrm{Fm}) \\
\text { of } 2 \text { nd date }\end{array}$ & $\begin{array}{l}\text { Grain } \\
\text { yield }\end{array}$ & $\begin{array}{c}1,000 \\
\text { seed } \\
\text { weight }\end{array}$ & $\begin{array}{c}\text { Grains per } \\
\text { panicle }\end{array}$ & $\begin{array}{c}\text { Dryleaf } \\
\text { percentage at } \\
\text { maturity stage }\end{array}$ \\
\hline $\begin{array}{l}\text { Replication } \\
\text { (R) }\end{array}$ & 2 & $401.7^{\mathrm{ns}}$ & $10.4^{\mathrm{ns}}$ & $42.4^{\mathrm{ns}}$ & $97.98^{\mathrm{ns}}$ & $0.0197^{\mathrm{ns}}$ & $0.0031^{\mathrm{ns}}$ & $0.0002^{\mathrm{ns}}$ & $3.34^{\mathrm{ns}}$ & $42^{\mathrm{ns}}$ & $85266^{*}$ & $0.022^{\mathrm{ns}}$ \\
\hline $\begin{array}{c}\text { Water } \\
\text { stress }(\mathrm{S})\end{array}$ & 2 & $1829^{*}$ & $138.9^{*}$ & $697.2^{*}$ & $293.3^{*}$ & $0.23^{*}$ & $0.0128^{\text {ns }}$ & $0.0007^{\mathrm{ns}}$ & $21.5^{* *}$ & $124^{*}$ & $85564^{*}$ & $0.3824^{*}$ \\
\hline $\begin{array}{c}\text { Error a } \\
\text { (rxa) }\end{array}$ & 4 & 414.6 & 14.9 & 140.16 & 30.95 & 0.021 & 0.0027 & 0.0001 & 0.7 & 32 & 8589.4 & 0.0268 \\
\hline $\begin{array}{c}\text { Genotype } \\
(G)\end{array}$ & 9 & $274.8^{* *}$ & $15.4^{* *}$ & $217.2^{* *}$ & $143.1^{* *}$ & $0.157^{* *}$ & $0.00628^{*}$ & $0.0007^{* *}$ & $8.3^{* *}$ & $153^{* *}$ & $319251^{* *}$ & $0.0 .019^{\mathrm{ns}}$ \\
\hline$S_{x G}$ & 18 & $98.2^{\mathrm{ns}}$ & $3.7^{\mathrm{ns}}$ & $70.85^{* *}$ & $18.3^{\mathrm{ns}}$ & $0.055^{* *}$ & $0.0033^{\mathrm{ns}}$ & $0.0009^{* *}$ & $2.4^{* *}$ & $14 \mathrm{~ns}$ & $39641^{*}$ & $0.0483^{*}$ \\
\hline Errorb & 54 & 86.4 & 4.98 & 5.34 & 20.4 & 0.021 & 0.00264 & 0.000214 & 0.4 & 9 & 17760 & 0.02196 \\
\hline
\end{tabular}
a reducing trend: 439, 361 and 338 under zero, medium and severe drought conditions respectively.

Ns, ${ }^{*}$ and ${ }^{* *}$ : Non-significant, significant at 5 and $1 \%$ probability level, respectively 
Table 2. Mean comparison of the effect of water stress on physiological traits in grain sorghum genotypes

\begin{tabular}{|c|c|c|c|c|c|c|c|c|c|c|c|}
\hline Treatments & $\begin{array}{c}\text { Stomatal } \\
\text { conductance }\end{array}$ & $\begin{array}{c}\text { Canopy } \\
\text { temperature }\end{array}$ & $\begin{array}{l}\text { Relative } \\
\text { water } \\
\text { content } \\
\text { (RWC) }\end{array}$ & $\begin{array}{l}\text { Chlorophyll } \\
\text { index } \\
\text { (SPAD) }\end{array}$ & $\begin{array}{l}\text { Radiation } \\
\quad \text { use } \\
\text { efficiency } \\
\text { (REU) }\end{array}$ & $\begin{array}{l}(\mathrm{FV} / \mathrm{Fm}) \\
\text { of 1st date }\end{array}$ & $\begin{array}{l}\text { (FV/Fm) } \\
\text { of } 2 \text { nd date }\end{array}$ & $\begin{array}{l}\text { Grain } \\
\text { yield }\end{array}$ & $\begin{array}{c}1,000 \\
\text { seed } \\
\text { weight }\end{array}$ & $\begin{array}{l}\text { Panicle } \\
\text { seed } \\
\text { number }\end{array}$ & $\begin{array}{c}\text { Dryleaf } \\
\text { percentage at } \\
\text { maturity stage }\end{array}$ \\
\hline \multicolumn{12}{|l|}{ Water stress } \\
\hline S1 & $33.03 \mathrm{a}$ & $28.1 \mathrm{~b}$ & $75.9 a$ & $42.6 \mathrm{a}$ & $0.32 b$ & $0.149 \mathrm{a}$ & $0.087 \mathrm{a}$ & $3.3 a$ & $25.4 \mathrm{a}$ & $439 a$ & $28 \mathrm{~b}$ \\
\hline S2 & $17.7 \mathrm{~b}$ & $31.8 \mathrm{a}$ & $66.87 \mathrm{~b}$ & $36.7 b$ & $0.48 \mathrm{a}$ & $0.182 \mathrm{a}$ & $0.097 \mathrm{a}$ & $1.6 \mathrm{c}$ & $21.3 b$ & $338 b$ & $44 a$ \\
\hline S3 & $22.93 \mathrm{ab}$ & $31.9 \mathrm{a}$ & $68.6 \mathrm{ab}$ & $41.4 \mathrm{a}$ & $0.35 b$ & $0.187 \mathrm{a}$ & $0.089 a$ & $2.4 \mathrm{~b}$ & $23.2 \mathrm{ab}$ & $361 b$ & $48 a$ \\
\hline \multicolumn{12}{|l|}{ Genotypes } \\
\hline 'KGS29' & $28.6 \mathrm{ab}$ & $31.5 \mathrm{ab}$ & $62.7 \mathrm{~g}$ & $37.7 \mathrm{bc}$ & $0.36 \mathrm{bc}$ & $0.177 \mathrm{abc}$ & $0.086 b c$ & $0.25 b$ & $24.6 \mathrm{ab}$ & $240 \mathrm{de}$ & $43 \mathrm{ab}$ \\
\hline 'MGS2' & $27.8 \mathrm{ab}$ & $31.6 \mathrm{a}$ & $70.6 \mathrm{e}$ & $47.6 \mathrm{a}$ & $0.59 \mathrm{a}$ & $0.138 c$ & $0.097 \mathrm{ab}$ & $0.37 \mathrm{a}$ & $23.4 \mathrm{ab}$ & $373 \mathrm{~cd}$ & $47 a$ \\
\hline 'KGS33’ & $25.4 \mathrm{ab}$ & $31.4 \mathrm{ab}$ & $64.8 \mathrm{f}$ & $37.6 \mathrm{bc}$ & $0.48 \mathrm{ab}$ & $0.152 b c$ & $0.086 b c$ & $0.22 b$ & $23.1 \mathrm{~b}$ & $253 \mathrm{de}$ & $42 \mathrm{ab}$ \\
\hline 'Sepideh' & $23.3 \mathrm{ab}$ & $31.6 \mathrm{ab}$ & $64.2 \mathrm{f}$ & $41.1 \mathrm{~b}$ & $0.47 \mathrm{ab}$ & $0.156 b c$ & $0.087 b c$ & $0.28 b$ & $23.3 \mathrm{ab}$ & $224 \mathrm{e}$ & $39 \mathrm{ab}$ \\
\hline 'KGFS27' & $10.94 \mathrm{c}$ & $31.9 \mathrm{a}$ & $74.5 b c$ & $37.9 \mathrm{bc}$ & $0.11 \mathrm{~d}$ & $0.222 \mathrm{a}$ & $0.077 \mathrm{c}$ & $\begin{array}{c}0.09 \\
\mathrm{~cd}\end{array}$ & $11.9 \mathrm{c}$ & $814 a$ & $47 a$ \\
\hline 'MGS5' & $25.3 \mathrm{ab}$ & $30.6 \mathrm{abc}$ & $75.6 \mathrm{ab}$ & $47.1 \mathrm{a}$ & $0.47 \mathrm{ab}$ & $0.15 b c$ & $0.098 \mathrm{ab}$ & $0.15 c$ & $26 a$ & $287 \mathrm{cde}$ & $33 b$ \\
\hline 'KGFS5' & $22.7 \mathrm{~b}$ & $28.3 \mathrm{~d}$ & $72.9 \mathrm{~cd}$ & $40.1 b c$ & $0.37 b c$ & $0.189 \mathrm{ab}$ & $0.091 \mathrm{~b}$ & $0.07 \mathrm{~d}$ & $25.4 \mathrm{ab}$ & 317 cde & $43 \mathrm{ab}$ \\
\hline 'KGFS17’ & $24.7 \mathrm{ab}$ & $31 \mathrm{ab}$ & $76.9 a$ & $38.5 b c$ & $0.3 c$ & $0.193 \mathrm{ab}$ & $0.107 \mathrm{a}$ & $0.1 \mathrm{~cd}$ & $23.9 \mathrm{ab}$ & $421 c$ & $37 \mathrm{ab}$ \\
\hline 'KGFS13' & $24.7 \mathrm{ab}$ & $29.5 \mathrm{bcd}$ & $70.6 \mathrm{e}$ & $36.5 c$ & $0.32 c$ & $0.157 b c$ & $0.099 \mathrm{ab}$ & $0.1 \mathrm{~cd}$ & $25.8 \mathrm{ab}$ & $594 \mathrm{~b}$ & $38 \mathrm{ab}$ \\
\hline 'KGFS30' & $32.1 \mathrm{a}$ & $28.8 \mathrm{~cd}$ & $71.2 \mathrm{de}$ & $37.9 \mathrm{bc}$ & $0.36 b c$ & $0.193 \mathrm{ab}$ & $0.086 b c$ & $0.06 \mathrm{~d}$ & $25.4 \mathrm{ab}$ & $274 \mathrm{de}$ & $36 \mathrm{ab}$ \\
\hline
\end{tabular}

Means in each column, followed by at least one letter in common are not significantly different at the $5 \%$ probability LSD Test. S1 = Normal irrigation, S2 = Irrigation cut off in vegetative stage, $\mathrm{S} 3$ = Irrigation cut off in generative stage

Table 3. Mean comparison of the effect of different level of water stress and genotypes on physiological characteristics in grain sorghum

\begin{tabular}{|c|c|c|c|c|c|c|c|}
\hline Water stress & Genotypes & $\begin{array}{l}\text { Relative water } \\
\text { content } \\
\text { (RWC) }\end{array}$ & $\begin{array}{l}\text { Radiation use } \\
\text { efficiency } \\
\text { (RUE) }\end{array}$ & $\begin{array}{c}(\mathrm{FV} / \mathrm{Fm}) \text { of } 2 \mathrm{nd} \\
\text { date }\end{array}$ & Grain yield & $\begin{array}{l}\text { Grains per } \\
\text { panicle }\end{array}$ & $\begin{array}{c}\text { Dry leaf } \\
\text { percentage at } \\
\text { maturity stage }\end{array}$ \\
\hline S1 & KGS29 & 72 efghi & 0.39 bcdefghi & 0.097 bcde & $3.4 \mathrm{de}$ & 274 ghi & $24 x$ \\
\hline S1 & MGS2 & $75 \mathrm{cdef}$ & 0.61 abcde & 0.09 bcdef & 2 fghij & $445 \mathrm{cdefg}$ & $21 \mathrm{z}$ \\
\hline S1 & KGS33 & $64 \mathrm{~lm}$ & 0.54 abcdef & $0.087 \mathrm{cdef}$ & 2.2 defghij & 278 ghi & $27 \mathrm{u}$ \\
\hline S1 & Sepideh & 72 efghi & 0.24 fghij & 0.1 bcde & 2.1 efghij & $188 \mathrm{i}$ & $24 w$ \\
\hline S1 & KGFS27 & $78 \mathrm{abcd}$ & $0.03 \mathrm{j}$ & $0.073 \mathrm{def}$ & 2.3 defghij & $773 \mathrm{~b}$ & $31 \mathrm{~s}$ \\
\hline S1 & MGS5 & $81 \mathrm{ab}$ & 0.34 defghij & $0.1 \mathrm{bcde}$ & 3 defg & 419 defgh & $31 \mathrm{~s}$ \\
\hline S1 & KGFS5 & $79 \mathrm{abc}$ & 0.31 defghij & 0.09 bcdef & $3.6 \mathrm{~cd}$ & 336 fghi & $22 y$ \\
\hline S1 & KGFS17 & $82 \mathrm{a}$ & 0.25 fghij & 0.08 cdef & $4.9 \mathrm{bc}$ & $663 \mathrm{bc}$ & $38 \mathrm{o}$ \\
\hline S1 & KGFS13 & $80 \mathrm{abc}$ & 0.3 efghij & $0.087 \mathrm{cdef}$ & $6.8 \mathrm{a}$ & $659 \mathrm{bc}$ & 38 o \\
\hline S1 & KGFS30 & $78 \mathrm{abcd}$ & 0.18 hij & 0.07 ef & $3.2 \mathrm{def}$ & 364 fghi & $25 \mathrm{v}$ \\
\hline S2 & KGS29 & $55 \mathrm{p}$ & 0.36 cdefghi & $0.063 \mathrm{f}$ & 1.5 hijk & $186 \mathrm{i}$ & $40 \mathrm{~m}$ \\
\hline S2 & MGS2 & 70 ghijk & 0.51 abcdefg & $0.11 \mathrm{ab}$ & 2 efghij & 290 ghi & $45 \mathrm{i}$ \\
\hline S2 & KGS33 & 68 hijk & $0.69 \mathrm{ab}$ & $0.087 \mathrm{cdef}$ & $0.95 \mathrm{jk}$ & $200 \mathrm{i}$ & $54 \mathrm{f}$ \\
\hline S2 & Sepideh & $66 \mathrm{jklm}$ & $0.7 \mathrm{a}$ & 0.09 bcdef & $1.3 \mathrm{ijk}$ & 267 ghi & $36 \mathrm{p}$ \\
\hline S2 & KGFS27 & 73 defg & 0.21 ghij & 0.093 bcdef & 2.7 defgh & $1043 \mathrm{a}$ & $42 \mathrm{k}$ \\
\hline S2 & MGS5 & 76 bcde & 0.46 abcdefgh & $0.103 \mathrm{bcd}$ & 1.7 ghijk & $179 \mathrm{i}$ & $39 n$ \\
\hline S2 & KGFS5 & 69 ghijk & 0.47 abcdefgh & $0.11 \mathrm{abc}$ & $0.45 \mathrm{k}$ & $181 \mathrm{i}$ & $67 c$ \\
\hline S2 & KGFS17 & 73 efgh & 0.39 abcdefghi & 0.1 bcde & 1.9 fghij & 240 ghi & $31 \mathrm{r}$ \\
\hline S2 & KGFS13 & 56 op & 0.36 cdefghi & $0.12 \mathrm{ab}$ & 2.5 defghi & $532 \mathrm{cdef}$ & $45 \mathrm{i}$ \\
\hline S2 & KGFS30 & $65 \mathrm{klm}$ & $0.68 \mathrm{ab}$ & 0.09 bcdef & 1.4 hijk & 265 ghi & $48 \mathrm{~g}$ \\
\hline S3 & KGS29 & $62 \mathrm{mn}$ & 0.32 defghij & 0.097 bcde & 2.2 efghij & 262 ghi & $66 \mathrm{~d}$ \\
\hline S3 & MGS2 & $67 \mathrm{ijkl}$ & $0.65 \mathrm{abc}$ & 0.09 bcdef & 2.5 defghi & 385 efghi & $74 \mathrm{a}$ \\
\hline S3 & KGS33 & $63 \operatorname{lmn}$ & 0.21 ghij & $0.083 \mathrm{cdef}$ & 2 efghij & 281 ghi & $46 \mathrm{~h}$ \\
\hline S3 & Sepideh & 59 no & 0.48 abcdefgh & $0.07 \mathrm{ef}$ & 1.9 fghij & $218 \mathrm{hi}$ & $59 e$ \\
\hline S3 & KGFS27 & 73 efgh & $0.08 \mathrm{ij}$ & $0.063 \mathrm{f}$ & $1.2 \mathrm{ijk}$ & $625 \mathrm{bcd}$ & $67 \mathrm{~b}$ \\
\hline S3 & MGS5 & 70 ghijk & $0.62 \mathrm{abcd}$ & 0.09 bcdef & 2.4 defghi & 262 ghi & $28 \mathrm{t}$ \\
\hline S3 & KGFS5 & 71 fghij & 0.34 defghij & $0.073 \mathrm{def}$ & $3.1 \mathrm{def}$ & 436 defgh & 411 \\
\hline S3 & KGFS17 & 76 bcde & 0.26 fghij & $0.14 \mathrm{a}$ & 1.9 fghij & 359 fghi & $43 \mathrm{j}$ \\
\hline S3 & KGFS13 & 77 bcde & 0.3 efghij & 0.09 bcdef & $5.9 \mathrm{ab}$ & 590 bcde & $34 \mathrm{q}$ \\
\hline S3 & KGFS30 & 70 fghijk & 0.23 ghij & 0.097 bcde & 1.9 fghij & $193 \mathrm{i}$ & $36 \mathrm{p}$ \\
\hline
\end{tabular}

Means in each column, followed by at least one letter in common are not significantly different at the 5\% probability LSD Test. S1 = Normal irrigation, S2 = Irrigation cut off in vegetative stage, $\mathrm{S} 3$ = Irrigation cut off in generative stage

Grain yield reduction under drought condition has been widely reported in the literature (Sinclair et al., 1990; Kebede et al., 2001; Ejeta and Knoll, 2007). The yield loss is driven by reduction in both grain numbers per panicle and 1,000 seed weight (Prasad et al., 2008). Drought stress imposition before pollination in sorghum is concerned to the reduction of the seed number per panicle, but the stress effect after pollination reduces the 1,000 seed weight (Eastin et al., 1983).

The most critical stage in sorghum in terms of yield reduction under drought stresses is grain filling period, which starts from about 10 days before flowering until the end of flowering (Prasad et al., 2008). Inflorescence meristem 
208

differentiation process in sorghum is completed within 5 to 6 days, which is the period in which drought stress can greatly reduce the number of seeds per panicle (Smith and Frederiksen, 2000).

Analysis of variance showed that both drought and genotype factors had significant effects on stomatal conductance, but their interaction on the trait remained neutral (Table 1). Means comparison illustrated that stomatal conductance reduced from 33 at no stress condition to 17 in severe stress condition, giving $46 \%$ reduction as compared with the control. Amongst the genotypes, 'KGFS30' had the highest and 'KGFS27' the lowest stomatal conductance. Studies show that drought-tolerant varieties had higher stomatal conductance compared with the sensitive ones.

High stomatal conductance can be related to a larger root system (higher water absorption) or better osmotic adjustment (higher water use efficiency) which is part of plant avoidance mechanisms (Cushman and Bohnert, 2003). Based on the relationship between stomatal conductance and yield, researchers reported significant negative correlation between the rate of photosynthesis and stomatal resistance (Cox and Juliff, 1986). Researchers believed that stomatal closure under drought stress limits the $\mathrm{CO}_{2}$ flow to photosynthetic locations and decline the carbon exchange rate (CER) (Raper and Kramer, 1987). However, recent studies suggest that inhibition of metabolism in the chloroplasts may play a more important role than stomatal closure to reduce the CER.

Drought and genotype had significant effects on canopy temperature (Table 1), but their interaction on the trait was not-significant. The means comparison showed an increase of canopy temperature with drought, being the highest in medium and severe stress and the lowest in zero drought condition. Amongst the genotypes, 'KGFS27' and 'MGS2' had the highest and 'KGFS30' and 'KGFS5' commonly had the lowest canopy temperature, respectively (Table 2).

Genotypes 'KGFS27' and 'MGS2' that had the highest canopy temperature demonstrated the lowest stomatal conductance and genotypes 'KGFS30' and 'KGFS5' with the lowest canopy temperature had the highest stomatal conductance, giving a better transpiration.

Canopy temperature can be used as a criterion of drought resistant genotypes in wheat and millet (Golestani and Assad, 1998). It has been also reported as effective way to understand the situation of drought stress in sorghum (Schaffert et al., 2011). In drought tolerant genotypes, leaf temperature is lower than in the case of sensitive cultivars; for this reason, leaf temperature could be a good criterion for selection of tolerant genotypes (Hosseini Salekdeh et al., 2009).

The effects of drought, genotype and their interaction on leaf relative water content (LRWC) were significant (Table 1). The highest LRWC mean value $(75.9 \%)$ was observed under no stress condition, whereas it decreased to the lowest value $(66.9 \%)$ under severe drought. The highest relative water content was recorded in 'MGS5' and 'KGFS17' and the lowest in 'KGS33' and 'Sepideh' (Table 2). The interaction between genotype and drought showed 'KGFS17' to have the highest relative water content (RWC) at no drought stress and 'KGS29' the lowest RWC at severe drought stress treatment (Table 3).

In response to drought, plants adopt physiological changes in their bodies to tackle the stress. For instance, it has been shown that wheat genotypes increased their RWC as a response to drought stress (Rascio et al., 1998). One of the important strategies of plants in drought tolerance is osmotic adjustment, which is highly correlated with leaf relative water content (Schonfeld et al., 1988). Drought stress decreases relative water content and in fact the genotypes that hold large amounts of water in their bodies without closing stomata, are suitable for dry areas.

The results of analysis of variance (Table 1) showed drought and genotype had significant effects on chlorophyll index (SPAD), while their interaction had no effect on the trait. Chlorophyll index decreased as the rate of drought stress increased. Amongst the genotypes, 'MGS2' and 'MGS5' had the highest SPAD index and 'KGS29' and 'KGS33' had the lowest value (Table 2).

Chlorophyll reduction under drought stress can be attributed to the changes in ratio of protein to lipid in protein compounds or in the increase of chlorophyllase enzyme activity. Literature suggests that reduction in leaf water potential in wheat can increase chlorophyllase activity (Parida et al., 2004). Chlorophyll reduction with the stress can be also promoted by chloroplasts injuries caused by reactive oxygen species (Agastian et al., 2000).

Chlorophyll fluorescence was measured at two stages. The first data collection was taken 30 days after imposing the medium drought stress and the second stage was performed 45 days after the severe drought stress. The results at the first stage showed that genotype had significant effects on FV/Fm ratio, while it remained unaffected with the drought stresses. Between the genotypes, 'KGFS27' had highest quantum yield and 'MGS2', 'MGS5' and 'KGS33' together had the lowest value (Table 2 ). At the second stage, both drought stress and genotype significantly affected $\mathrm{FV} / \mathrm{Fm}$ ratio in which the quantum yield in 'KGFS17', 'KGFS13', 'MGS5' and 'MGS2' had higher values than the others (Table 2).

Photochemical efficiency of photosystem II $(\mathrm{Fv} / \mathrm{Fm})$ is a good criterion in assessing photosynthetic system of plant. In a study on winter wheat under drought stress, it was concluded that photochemical efficiency of photosystem II was not affected by drought stress (Shanggun et al., 2000). It was also reported that drought stress on wheat darkness adapted varieties had no effects on the efficiency of photosystem II (Gale et al., 2002).

Drought, genotype and their interaction had significant effects on radiation use efficiency (RUE) (Table 1). The means comparison showed that severe drought stress had the highest effect on RUE and the medium and no drought stress together had the lowest. Genotypes 'MGS2', 'KGS33', 'MGS5' and 'Sepideh' had the highest RUE values, while 'KGFS27' had the lowest RUE (Table 2). The interaction between the factors illustrated that 'Sepideh' in severe drought stress had the highest and 'KGFS27' at no stress level had the lowest RUE respectively (Table 3 ). It has been reported that radiation use efficiency increased under drought conditions if a better distribution of photosynthetically active radiation in the plant canopy took place. It was also emphasized that the effects of drought stress on yield loss through reducing the leaf area and leaf accelerated senescence was much more significant than its effects on photosynthesis alone (Araus et al., 2003).

Effects of drought on the percentage of dried leaves at the maturity stage were significant while the genotypes had no 
effect on the trait (Table 1). The highest percentage of dry leaves in maturity stage occurred at severe and medium drought stresses. This attribute is a measure of stay-green index in genotypes. Plants with high staygreen index are more resistant to drought-induced senescence. In such plants, green leaves live longer and produce more grains (Borrell et al., 2003). Cultivars with high stay-green index have more active transport system in the stem under severe drought stress (Xue et al., 2000; Awala and Wilson, 2005). Leaf area index of such genotypes ranged between 1.6-4.55, that are desirable values in better light absorbance and thus plants assimilate storage for reproductive organs, maximizing the yield (Kumari Vinodhane and Ganesamurthy, 2010).

\section{Conclusions}

Plants suffer several physiological changes during drought stress and thereby they respond to stress. Since the development of yield is usually difficult due to its low heritability, it is very important to consider other aspects of drought resistance such as physiological indicators (stomatal conductance, chlorophyll index, relative water content, chlorophyll fluorescence, canopy temperature, radiation use efficiency, stay-green etc.) because of their low cost of determination. Generally, physiological traits are complementary and good alternatives for morphological traits, as they provide further and complete information for cultivars ' breeding. The hereby experiment on 10 genotypes of sorghum some of the studied physiological traits such as relative water content, chlorophyll index and stomatal conductance decreased in drought stress conditions, while canopy temperature and radiation use efficiency increased during drought stress.

\section{Acknowledgements}

The authors would like to acknowledge Zabol University and South Khorasan Agricultural and Natural Resources Research and Education Center, for facilitating of this study. In addition, the authors thank Dr. Sanjari and Dr. Goldani for language editing of this paper.

\section{References}

Agastian P, Kingsley SJ, Vivekanandan M (2000). Effect of salinity on photosynthesis and biochemical characteristics in mulberry genotypes. Photosynthetica 38:287-290.

AghaAlikhani M, Etemadi F, Fouman A (2012). Physiological basis of difference in grain sorghum (Sorghum bicolor L.Moench) in a semi-arid environment. Asian Research Publishing Network of Agriculture and Biological Science 7(7):488-496.

Ali MA, Abbas, A, Niaz S, Zulkiffal M, Ali S (2009). Morphophysiological criteria for drought tolerance in sorghum (Sorghum bicolor) at seedling and post-anthesis stages. International Journal of Agricultural Biology 11:647-680.

Araus JL, Bort J, Steduto P, Villegas D, Royo C (2003). Breeding cereals for Mediterranean conditions: ecophysiological clues for biotechnology application. Annals of Applied Biology 142:129141.

Aruna C, Audilakshm S (2008). A strategy to identify potential germplasm for improving yield attributes using diversity analysis in sorghum. Plant Genetic Resources 6:187-194.

Awala SK, Wilson JP (2005). Expression and segregation of stay-green in pearl millet. International Sorghum and Millets Newsletter 46:97-100.

Blum A (1988). Salinity resistance. In: Plant breeding for stress environments. CRC Press.

Borell AK, Oosterom EJV, Hammer GL, Jordan D, Douglas A (2003). The physiology of "stay-green" in sorghum. Proceedings of the 11 Australian Agronomy Conference pp 2-6.

Chaves MM, Marococ JP, Pereira JS (2003). Understanding plant responses to drought: from genes to the whole plant. Functional Plant Biology 30:239-264.

Cornic G (2000). Drought stress inhibits photosynthesis by decreasing stomatal aperture - not by affecting ATP synthesis. Trends in Plants Science 5(5):187-188.

Cox WJ, Juliff GD (1986). Growth and yield of sunflower and soybean under soil water deficits. Agronomy Journal 78:226-230.

Cushman JC, Bohnert HJ (2003). Genomic approaches to plant stress tolerance. Current Opinion in Plant Biology 3(2):117-124.

Eastin JD, Castleberry RM, Gerik TJ, Hultquist JH, Mahalakshmi V, Ogunlela VB, Rice JR (1983). Physiological aspects of high temperature and drought stress. In: Raper CD, Kramer J (Eds). Crop reactions to water and temperature stresses in humid, temperature climates. Westview Press, Boulder, CO, USA pp 91112.

Ejeta G, Knoll JE (2007). Marker-assisted selection in sorghum. In: Varshney RK, Tuberosa R (Eds). Genomic-assisted crop improvement. Genomics Applications in Crops Vol 2 pp:187205.

Entz MH, Flower DB (1990). Differential agronomic responses of winter wheat cultivars to pre-anthesis environmental stress. Crop Science 30:1119-1123.

Flexas J, Bota J, Loreta F, Cornic G, Sharkey TD (2004). Diffusive and metabolic limitation to photosynthesis under drought and salinity in C3 plants. Plant Biology 6:269-279.

Gale A, Csiszar J, Tari I, Erdei L (2002). Change in water and chlorophyll fluorescence parameters under osmotic stress in wheat cultivars. Proceeding of the 7 th Hungarian congress on Plant Physiology pp 85-86.

Golestani AS, Assad MT (1998). Evaluation of four screening techniques for drought resistance and their relationship to yield reduction ratio in wheat. Euphytica 103:293-299.

Grafts-Brander SJ, Salvucci ME (2002). Sensitivity of photosynthesis in a C4 plant, maize, to heat stress. Plant Physiology 129:17731780.

Hammer GL, Vanoosterom E, McLean G, Chapman SC, Broad I, Harland P, Muchow RC (2010). Adapting APSIM to model the physiology and genetics of complex adaptive traits in feld crops. Journal of Experimental Botany 61:2185-2202.

Hosseini Salekdeh GR, Mattew Bennett J, Boyer J (2009). 
210

Conceptual framework for drought phenotyping during molecular breeding. Trends in Plant Science 14:1360-1385.

Jensen HE, Svendsen H, Jensen SE, Mogensen VO (1990). Canopyair temperature of crops growth under different irrigation regimes in a temperate humid climate. Irrigation Science 11:181-188.

Kebede H, Subudhi PK, Rosenow DT, Nguyen HT (2001). Quantitative trait loci influencing drought tolerance in grain sorghum (Sorghum bicolor L. Moench). Theoretical and Applied Genetics 103:266-276.

Kluitenberg GJ, Biggar JW (1992). Canopy temperature as a measure of salinity stress on sorghum. Irrigation Science 13:115-121.

Kumari Vinodhana N, Ganesamurthy K (2010). Evaluation of morpho-physiological characters in sorghum (Sorghum bicolor (l.) Moench) genotypes under post-flowering drought stress. Electronic Journal of Plant Breeding 1(4):585-589.

Lichtenthaler HK (1998). In vivo chlorophyll fluorescence as a tool for stress detection in plants. In: Applications of chlorophyll fluorescence. Springer Netherlands pp 129-142.

Maman N, Mason SC, Lyon DJ, Dhungana P (2004). Yield components of pearl millet and grain sorghum across environments in the Central Great Plains. Crop Science 44:21382145.

Mutava RN (2012). Evaluation of sorghum genotypes for variation in canopy temperature and drought tolerance. $\mathrm{PhD}$ Thesis, Kansas State University, Manhattan, Kansas.

Prasad PVV, Pisipati SR, Mutava RN, Tuinstra MR (2008). Sensitivity of grain sorghum to high temperature stress during reproductive development. Crop Science 48:1911-1917.

Parida AK, Das AB (2004). Salt tolerance and salinity effect on plants: a review. Ecotoxicology and Environmental Safely 60:324-349.

Raper CD, Kramer PJ (1987). Stress physiology. In: Wilcox JR (Ed). Soybean-improvement, production and uses. American Society of Agronomy, Madison, WI, USA pp 589-642.

Rascio A, Russo M, Platani C, Difonzo N (1998). Drought intensity effects on genotypic differences in tissue affinity for strongly bound water. Plant Science 132:121-126.

Reynolds MP, Saint Pierre C, Saad ASI, Vargas M, Condon AG (2007). Evaluating potential genetic gains in wheat associated with stress adaptive trait expression in elite genetic resources under drought and heat stress. Crop Science 47:172-189.

Richards RA (1996). Increasing the yield potential of wheat: manipulating sources and sinks. In: Reynolds MP et al. (Eds). Increasing yield potential in wheat: breaking the barriers. Mexico, pp 134-149.
Schaffert RE, Albuquerque PEP, Duarte JO, Garcia JC, Gomide RL, Guimares CT, Magalhaes PC, Magalhaes JV, Queiroz V (2011). Phenotyping sorghum for adaptation to drought. Drought phenotyping in crops: from theory to practice. México, DF: CGIAR: CIMMYT pp 287-299.

Schonfeld MA, Johnson RC, Carver BF, Mornhinweg DW (1988). Water relations winter wheat as drought resistance indicators. Crop Science 28:526-531.

Shanggun Z, Shao M, Dyckmans J (2000). Effects of nitrogen nutrition and water deficit on net photosynthetic rate chlorophyll florescence in winter wheat. Plant Physiology 156:45-51.

Sinclair T, Bennetto RDM, Muchow RO (1990). Relative sensitivity of grain yield and biomass accumulation to drought in field grown maize. Crop Science 30:690-693.

Smith CW, Frederiksen (2000). Sorghum. John Wily \& Sons, Inc.

Terashima I, Ono K (2002). Effects of $\mathrm{HgCl} 2$ on $\mathrm{CO} 2$ dependence of leaf photosynthesis: evidence indicating involvement of aquaporins in $\mathrm{CO} 2$ diffusion across the plasma membrane. Plant Cell Physiology 43(1):70-78.

Tuinstra MR, Grote EM, Goldsbrough PB, Ejeta G (1997). Genetic analysis of postflowering drought tolerance and components of grain development in Sorghum bicolor (L) Moench. Molecular Breeding 3:439-448.

Wanous MK, Miller FR, Rosenow DT (1991). Evaluation of visual rating scales for green leaf retention in sorghum. Crop Science 31:1691-1694.

Weatherley PE (1950). Studies in the water relations of the cotton plant. The field measurement of water deficits in leaves. New Phytologist 49(1):81-97.

Xue W, Rosenow DT, Nguyen HT (2000). Stay green trait in grain sorghum: relationship between visual rating and leaf chlorophyll concentration. Plant Breeding 119(4):365-367.

Yamasaki T, Yamakawa T, Yamane Y, Koike H, Satoh K, Katoh S (2002). Temperature acclimation of photosynthesis and related changes in photosystem II electron transport in winter wheat. Plant Physiology 128:1087-1097.

Zhou J, Wang X, Jiao Y, Qin Y, Liu X, He K (2007). Global genome expression analysis of rice in response to drought and high-salinity stresses in shoot, flag leaf, and panicle. Plant Molecular Biology 63:591-608. 